\title{
Integrating a creativity, innovation, and design studio within an academic library
}

Holt Zaugg

Brigham Young University, holt_zaugg@byu.edu

Melissa C. Warr

Brigham Young University - Provo, melissa.c.warr@gmail.com

Follow this and additional works at: https://scholarsarchive.byu.edu/facpub

Part of the Library and Information Science Commons

\section{Original Publication Citation}

Holt Zaugg, Melissa C. Warr, (2018) "Integrating a creativity, innovation, and design studio within an academic library", Library Management, Vol. 39 Issue: 3/4, pp.172-187, https://doi.org/ 10.1108/LM-09-2017-0091

\section{BYU ScholarsArchive Citation}

Zaugg, Holt and Warr, Melissa C., "Integrating a creativity, innovation, and design studio within an academic library" (2018). Faculty Publications. 2062.

https://scholarsarchive.byu.edu/facpub/2062

This Peer-Reviewed Article is brought to you for free and open access by BYU ScholarsArchive. It has been accepted for inclusion in Faculty Publications by an authorized administrator of BYU ScholarsArchive. For more information, please contact ellen_amatangelo@byu.edu. 
Integrating a Creativity, Innovation, and Design Studio within an Academic Library

\section{Purpose}

This presentation describes the efforts to set up a Creativity, Innovation, and Design (CID) studio within an academic library. The presentation will describe the reasons for creating a CID studio, assessment of the pilot study, and next steps.

\section{Design, methodology or approach}

The assessment used surveys, interviews, focus groups and observations of students and faculty to determine how well the CID fits into the library.

\section{Findings}

Initial findings indicate that the CID studio is a good fit within the library space as learning activities in it support collaboration, discovery, and integration of library services. However, noise issues, equipment needs, and expansion of space are key future needs.

\section{Research or practical limitations or implications}

As libraries move from simple repositories of information to places of learning and collaboration, a CID studio space provides an opportunity to integrate learning opportunities with library services.

\section{Conclusions}

Through the first iteration, the CID has a unique and purposeful place within an academic library. It provides the opportunity for greater integration of library services. However, future iterations need to address key issues of space, equipment, and noise. 


\section{Introduction}

Libraries are no longer simple repositories of books, journals, and items used in academic research and teaching. Academic libraries are becoming places of collaboration and knowledge creation. At Brigham Young University (BYU), two of the Lee Library's three goals are to "provide spaces that facilitate collaboration, experimentation, creation, and discovery" and to "foster deep collaboration that produces new knowledge (research) and facilitates learning" (Paustenbaugh, 2013). These library goals dovetail with the broader university mission statement to "provide a period of intensive learning in a stimulated setting" (BYU Mission Statement, n.d.) and the aims of a BYU education to foster learning that is "intellectually enlarging, character building, and leading to lifelong service and learning” (Aims of a BYU Education, n.d.).

To accomplish similar goals other libraries are creating collaboration spaces for small and large groups. Two examples include media technology tools for recording, mixing, and editing that students would not be able to otherwise access, and Makerspaces for creating models and prototypes of designs. These spaces assist students in their creative and collaborative learning.

\section{Literature Review}

The Lee Library goals fall in line with national efforts to promote 21 st-century skills that prepare college graduates to work in collaborative, innovative environments (Coakes \& Smith, 2007; Partnership for 21st century skills: Framework for 21st-century learning, 2014). The collaborative efforts are a response to the educational disruption brought forth by globalization, environmental and economic sustainability, rapidly changing job markets, and technological advances (Gupta, 2015). These collaborative efforts often include members with diverse backgrounds and experience. The backbone of these collaborations is skills that promote innovation and creativity to serve others by creating products, services, and ideas that solve some 
of the world's most difficult problems (Banahan \& Playfoot, 2004; Ogunleye, 2006). Higher education courses in this area often include instruction in the four Cs - creativity, communication, critical thinking, and collaboration (Soulé and Warrick, 2015). A survey of 1,000 working college graduates indicated that college courses need to place greater emphasis on creativity, creative thinking, and integration of creativity into university curricula (Berland, 2012). Faculty need a space where they can draw students from across campus to teach interdisciplinary courses focused on creativity, innovation, and design.

Often the desire to promote creativity and innovation is manifest through the creation of spaces that promote the learning these skills through collaborative activities. Such efforts include Makerspaces that provide the materials and a location for people to work in collaborative ways to foster creativity and innovation (Curry, 2017). These spaces offer a place for social collaboration, but the location of the space and the services provided determine how useful the space may become. Bieraugel and Neill (2017) examined the use of such spaces both within and outside of libraries. Among their findings they discussed a Makerspace that was established in an engineering building and was well used by engineering students, but not many other students. The location of the Makerspace promoted its use by some, but hindered its use by others. The location of the space became as important as having a space.

In addition to an appropriate location, this space needs suitable pedagogical methods (Cennamo \& Brandt, 2012). These methods are somewhat different from traditional classes. Here faculty work with smaller classes in a student-centered approach (Brocato, 2009; Cennamo \& Brandt, 2012); Broadfoot \& Bennett, 2003; Brocato, 2009) with sufficient time to develop the creative and innovation skills while working on the problem (Brocato, 2009; 
Cennamo \& Brandt, 2012), and teaching approaches where faculty work "in the trenches" with the students as a resource and not just a dispenser of knowledge (Brandt et al., 2011).

These factors point to several components needed in a space devoted to teaching creativity and innovation in a higher education setting. The space needs to have access to multiple resources and a variety of spaces to accommodate large or small groups and individual work. It needs to have multiple resources to assist the creativity and innovation process. It needs to be in a location where one group does not appear to have "ownership" of the space over another group. Those teaching innovation and design need to approach instruction in a different way that includes key people who can help students along their way. An academic library is just such a place.

This case study describes the initial steps used at the Lee Library to develop a Creativity, Innovation, and Design (CID) studio within the library. Similar to other projects, the CID studio provides the space and tools that facilitate students learning how to apply creative activities to solve problems. Where possible, the course is interdisciplinary and centered on a real world problem often connected to outside partners. Unique to the Lee Library's CID studio is that courses taught there must fully integrate the skills and abilities of librarians as part of course instruction. In this way the space is not just set up for collaborative activities, but students and faculty learn what services and resources are readily available within the library to meet their needs and how to access them.

\section{Background}

In 2012, a small group of faculty at BYU created a CID group to promote these skills within university curricula. Over the next two years, these efforts developed into project-centered courses focused on developing these skills as part of an interdisciplinary collaboration. Often 
courses were housed within normal classrooms in specific colleges across campus. However, the normal classroom was ill suited for a space that fostered constant exchanges and movement among course participants. It included having to put out and pack away course materials after each class and not being able to access materials outside of class. Although faculty touted the courses as interdisciplinary, the college hosting the learning space seemed to have an upper hand as its students had greater familiarity with and ownership over the learning space.

As courses were developed, efforts increased to find a neutral home for these programs that would allow for learning activities unique to this type of course. The search led to the library as such a home because it has the feel of being a part of each discipline but solely belongs to none of them. Students and faculty viewed it as the "Switzerland" of campus, a place of complete neutrality, but one willing to host all collaborative efforts.

In 2014, the library removed three stacks in the Juvenile Literature section near the media center to open up a space for teaching these CID based courses. The space consisted of a large open teaching-collaboration space with three smaller group study rooms available for smaller group breakout sessions (see Figures 1 and 2). The larger open space included moveable furniture and white boards that groups could use in their collaboration efforts. All courses using the space were paired with librarians who would meet the needs of the group in terms of finding resources to aid in their collaboration. 


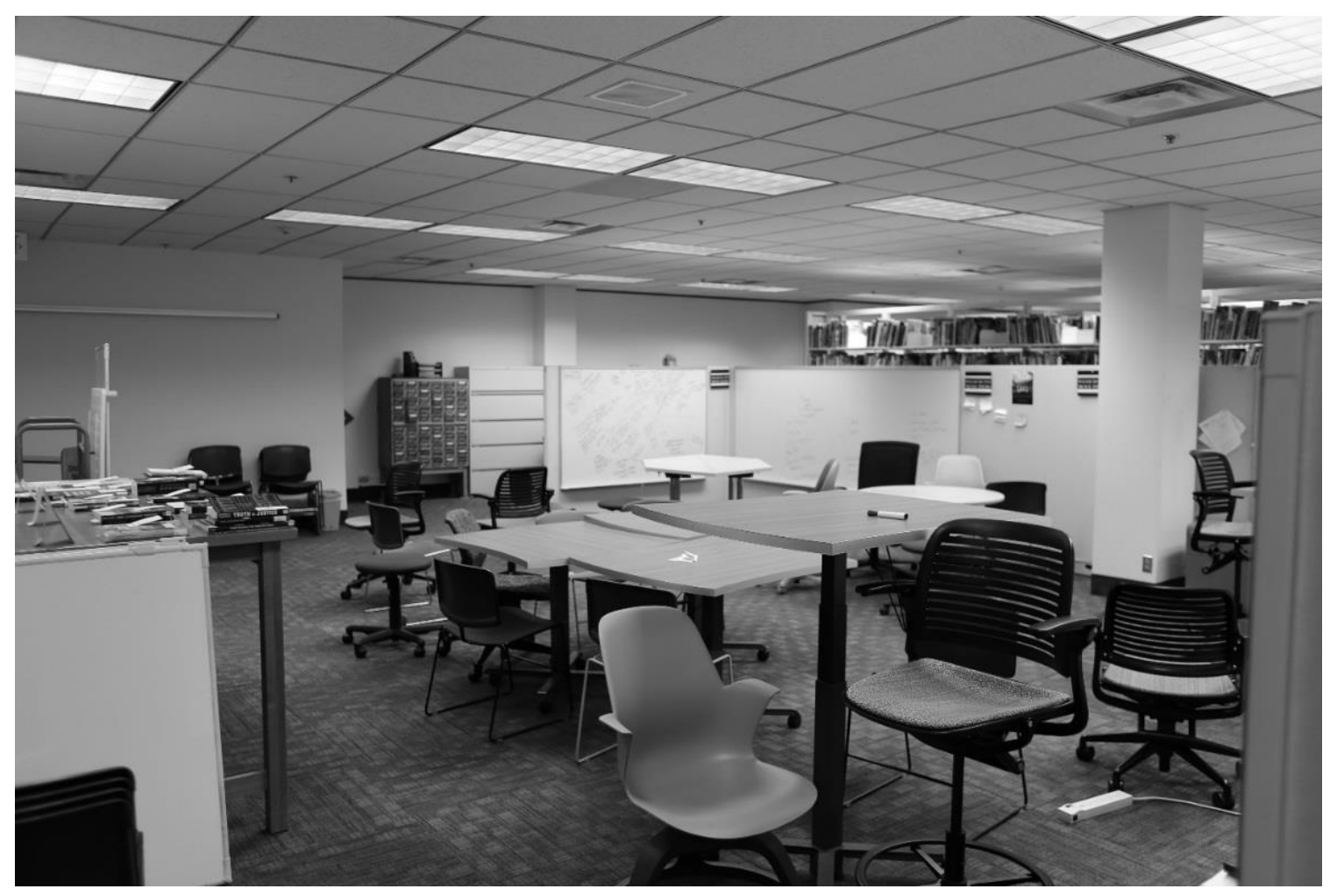

Figure 1. Creativity, Innovation, and Design Studio space in the Lee Library.

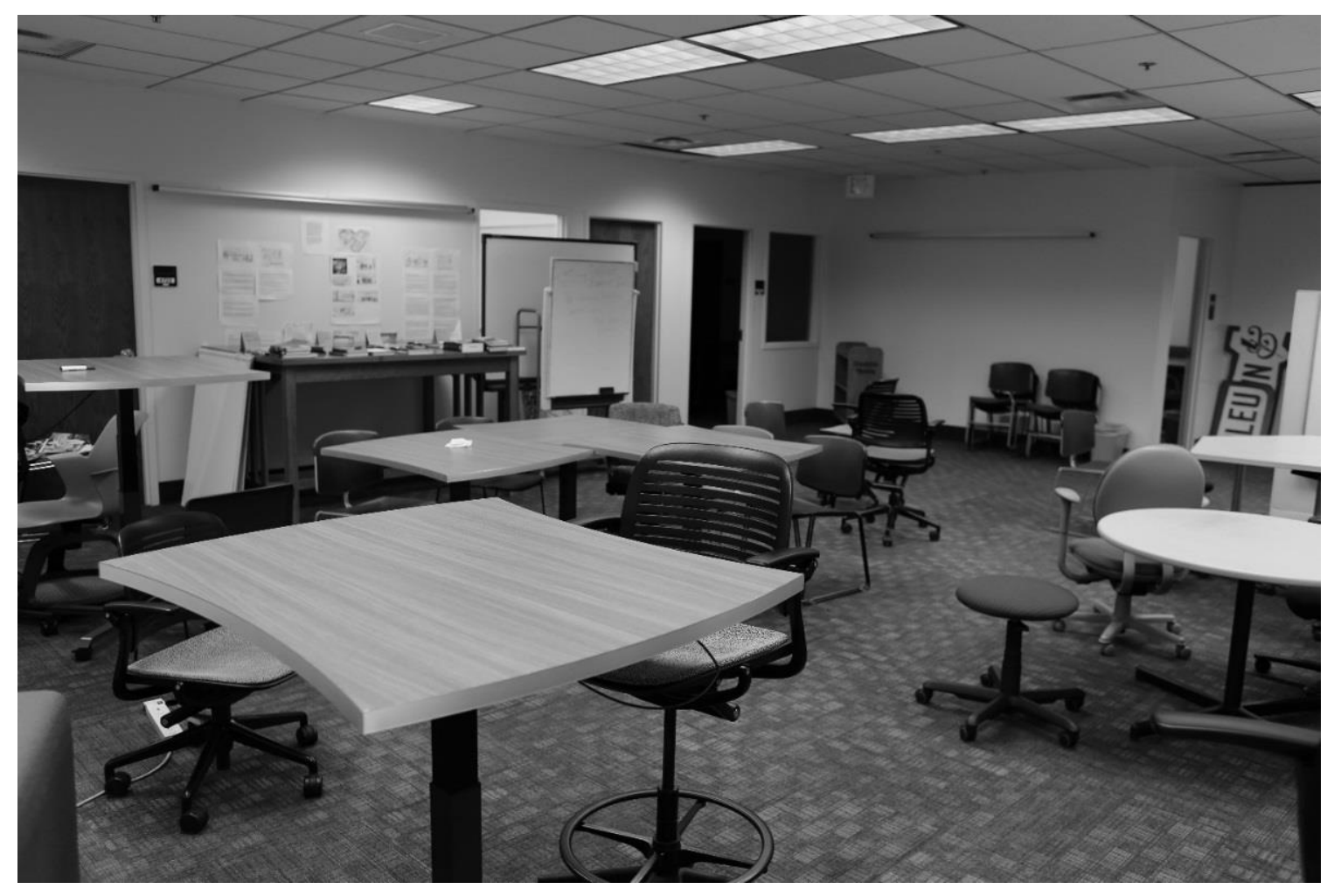

Figure 2. Creativity, Innovation, and Design Studio space in the Lee Library. 
As this effort was a phase 1 pilot study, we conducted assessments to determine the efficacy and use of the space, especially in terms of student learning. This paper reports on the initial assessment efforts and findings. It concludes with recommendations for next steps and factors to consider should a library consider creating such a space. It seeks to answer the questions:

1. Has this type of learning environment been effective at helping students learn their subject content as well as professional practices and processes important for careers?

2. How does this initiative help fulfill the mission and aims of BYU?

3. How does involving the Lee Library faculty as key partners in the courses benefit the stakeholders?

\section{Method}

The study examined 15 for-credit courses taught in the Lee Library's CID studio from the Winter (Jan-Apr) 2014 semester through to and including the Winter 2015 semester. Courses ranged from seminar (3-10 days) flexible credit courses to semester long courses. In addition to these courses, other courses used the CID studio for some but not all instruction. Additionally, several clubs and campus groups used this space after hours for their activities. However, only for-credit courses that taught all classes in the CID studio space were included in this study. We provide a description of the courses taught in the CID studio that were included in the study in Appendix A.

For some courses, we conducted pre-, mid-, and post-course surveys with students and instructors via online surveys. We also conducted observations on all courses. Often these observations included informal questions of students participating in the course. Finally, we conducted interviews with teaching faculty and focus groups with participating students at the end of each course. All interviews and focus group participants were volunteers from courses 
taught. Interviews were conducted at a time and location convenient to the researchers and participants. Focus groups were held in the library's focus group lab. We also interviewed a sample of faculty who taught creativity courses but did not use the CID studio space to compare experiences. Appendix B includes all questions asked on all surveys and in all interviews and focus groups.

As this case study was also an assessment to determine the efficacy of the space and whether it should continue beyond its prototype stage, all interviews and focus group comments were considered holistically. Often experiences within the CID studio were dependent on the project and learning that took place and were somewhat unique to students and faculty. For this reason, we do not express the percent of participants who had similar experiences, but offer a holistic perspective to attempt to describe the multiple experiences in the CID studio.

Open-ended comments from surveys and all comments from interviews and focus groups were examined for common themes. Once themes were identified comments were coded into those themes that helped to describe and understand the experience of students' and faculty in the CID studio. Findings from all data sources were triangulated to validate the experiences for students and faculty. These common experiences are briefly described, especially in the context of student learning in relation to library goals and university aims.

All participants in any data collection followed consent protocols as outlined in the Institutional Review Board (IRB) approved proposal. As the CID studio was a prototype, we made changes to the space based on experience and feedback, resulting in some changes to questions asked in the assessment. All changes to the assessment were IRB approved and assisted us to understand better how the CID studio functioned. 


\section{Findings}

A total of 111 students and 19 faculty participated in CID studio courses. Table 1 describes student and faculty participation by college. Table 2 lists the number of students in each course for each semester. Several students attended more than one CID course. Not all courses were interdisciplinary.

Of the 19 courses taught, 15 were interdisciplinary with students from at least two disciplines involved in the course. Business and engineering disciplines figured prominently in the courses taught because several of the founding members of the CID group were from these disciplines and already taught creativity and innovation courses. In this regard faculty were already using different pedagogies to guide students as they worked on their projects and learned how to develop creativity and innovation skills.

All courses were project based typically with partners outside of the university. Some projects were completed within the semester time frame while others extended beyond the semester. All projects had at least one librarian associated with the course to assist students with the resources available within the library.

\section{Table 1.}

Total Number of Students and Faculty Participating in the CID courses

\begin{tabular}{lcc}
\multicolumn{1}{c}{ Discipline } & Students & Faculty \\
\hline Business & 25 & 7 \\
Center for Teaching and Learning & - & 1 \\
Family Home \& Social Science & 3 & 2 \\
Education & 10 & 2 \\
Engineering & 8 & 3 \\
Fine Arts \& Communication & 36 & 1 \\
Humanities & 3 & 1 \\
International Studies & - & 1 \\
Life Sciences & 8 & 1 \\
Undeclared & 3 & - \\
Unknown & 15 & - \\
\hline Total & 111 & 19
\end{tabular}


Table 2.

Interdisciplinary Library Studio Courses and Research Sampling

\begin{tabular}{|c|c|c|c|}
\hline Semeste & Course Description & $\begin{array}{l}\text { No. of } \\
\text { Students }\end{array}$ & Student Disciplines \\
\hline \multirow{2}{*}{$\begin{array}{l}\text { Winter } \\
2014\end{array}$} & Fundación Paraguay & 16 & $\begin{array}{l}\text { Business, Advertising, } \\
\text { Visual Arts, Film }\end{array}$ \\
\hline & Writing and illustrating children's storybooks & 25 & $\begin{array}{l}\text { English, Visual Arts, } \\
\text { Advertising }\end{array}$ \\
\hline \multirow[t]{2}{*}{$\begin{array}{l}\text { Spring } \\
2014\end{array}$} & DUST & 40 & $\begin{array}{l}\text { Advertising, Visual Arts, } \\
\text { Music, Engineering, } \\
\text { Science, Education }\end{array}$ \\
\hline & Innovation boot camp & - & Unknown \\
\hline \multirow{5}{*}{$\begin{array}{l}\text { Fall } \\
2014\end{array}$} & DUST artifact creation & 4 & $\begin{array}{l}\text { Engineering, Life Science, } \\
\text { Education }\end{array}$ \\
\hline & Innovating scripture study tools & 10 & $\begin{array}{l}\text { Business, Engineering, } \\
\text { Communications }\end{array}$ \\
\hline & $\begin{array}{l}\text { Designing exhibits for Farm Country at } \\
\text { Thanksgiving Point }\end{array}$ & 14 & Education \\
\hline & $\begin{array}{l}\text { Acting as the business development team for a } \\
\text { biotech company }\end{array}$ & 5 & Life Science, Humanities \\
\hline & Individual social innovation projects & 10 & $\begin{array}{l}\text { Business, Life Science, } \\
\text { Humanities }\end{array}$ \\
\hline \multirow{6}{*}{$\begin{array}{l}\text { Winter } \\
2015\end{array}$} & Resources for Fundación Paraguay & 13 & $\begin{array}{l}\text { Business, Visual Arts, } \\
\text { Communications }\end{array}$ \\
\hline & Diplomacy museum for National Mall & 27 & $\begin{array}{l}\text { Business, Engineering, Fine } \\
\text { Arts, Humanities }\end{array}$ \\
\hline & Alternate reality game for BYU writing course & 4 & Engineering, English \\
\hline & Experience design & 13 & Business \\
\hline & Solutions journalism & 6 & $\begin{array}{l}\text { Education, Engineering, } \\
\text { Communications }\end{array}$ \\
\hline & Individual social innovation projects & 5 & Business \\
\hline
\end{tabular}

Some students participated in more than one course and were counted twice.

The remainder of the findings focus on how the CID studio functioned as an instructional setting and the pedagogy used for instruction. They also discuss how the studio meets the university's educational aims and the impact of having librarians embedded in the course instruction. 


\section{Instructional Setting and Pedagogy}

Courses taught in the CID studio were unique from other university-level courses in that the courses were project based and students designed their learning experience and workload assignments. Students often commented that they were not taking a course but engaging in a learning experience. This view often resulted in greater learning gains as exemplified by this student comment.

I feel that I can learn a lot more at a much faster rate because it ... is getting put to the test. Even though we have been working on one project the whole semester and will only have one final, I feel that I have learned and will probably retain more from this class than from many others I have taken [in college] because of the interactions and experiences I have had [in this course].

Students felt that the learning experience was more realistic and focused in real-world learning that would benefit them beyond the classroom and university experience. The flexibility in course design and workload also required students to take responsibility for their learning and challenge themselves at a level that fostered personal growth.

I am used to a class that is very structured. I do an initial part of the drawing, I show my professor, and get feedback from him, and then I go back, make changes, and keep reworking it until the finished product. I am more supervised under a professor. For the first time, I am on my own, I have to figure out those problems by myself and figure out a solution. So I feel like I grew up a lot as an artist.

This learning and flexibility the student experienced stretched across courses and discipline. Instead of being assigned roles and tasks, students determined where they fit in the project and 
what they could contribute to the final product. There was a sense of being able to blaze new trails, try ideas that may or may not work, and explore new skills that facilitate the project. Often students ended up putting in more work than they would in a normal class. We attribute this extra effort to the ownership students felt on the project. Instead of meeting the minimum requirements set by an instructor for a specific grade, students were engaged in completing the project. The learning motivation switched from extrinsic to an intrinsic motivation. In many cases, students worked alongside experts in a given field to complete the project designed to make a difference in the world and guide them to future employment.

When asked to rate their learning experience using parameters that were used for all CID studio courses, students consistently rated personal responsibility for making the project as good as possible high (4.45 out of 5). Other ratings of 4 or higher referred to students' deep personal motivation to do well (4.15), the freedom to make choices on the project (4.17), the choice of their role on the team (4.18), and the change in the relationship with the course instructor from other typical courses (4.17). While we report these ratings in aggregate, each course had comparable ratings. A summary of the aggregated ratings is found in Appendix C.

\section{Meeting University Aims}

Three aims of a BYU education (intellectually enlarging, character building, and leading to lifelong service and learning) were met within these CID project courses. We briefly discuss each aim.

Intellectually Enlarging. The "intellectual aims of a BYU education are intended to give students understanding, perspective, motivation, and interpersonal abilities—not just information and academic skills" (Aims of a BYU Education, n.d.). The CID courses fulfilled this university aim by having students work on teams requiring teamwork and interpersonal skills. They had to 
gain greater depth of understanding within their own discipline while connecting and learning with other disciplines. The courses fostered design thinking within a contextual learning experience that prepared students for future employment.

Team members brought forward a variety of ideas and concepts. Often students from one discipline would need to develop communication skills to help those in other disciplines understand their concepts or to be able to evaluate their ideas. This experience challenged students to increase their understanding and their interpersonal communication.

Character Building. The BYU educational aims indicate that learning should lead students "toward the balanced development of the whole person," including moral virtues such as "integrity, reverence, modesty, self-control, courage, compassion, and industry" (Aims of a BYU Education, n.d.). Additionally, students should be "capable of meeting personal challenge and change" (Aims of a BYU Education, n.d.). Students provided indicators of development in confidence, empathy, and humility as they worked with and understood their classmates better. They accepted critiques and improved from them. They learned to collaborate in new ways. Because the courses were student designed, participants had to develop self-control and industry in completing the collaborative tasks.

You stop and listen to each other and say, "Okay, I can really learn something from this person because they are adamantly telling me that they do it this way and I am adamantly telling them I do it this way. So let me try it out the way they are used to." And that is the only way you are really going to collaborate and meet middle grounds and learn.

Leading to Lifelong Service and Learning. This aim seeks to help students learn how to go forth to serve by strengthening not only themselves but also fellow classmates. Graduates 
"also bring strength to others in the tasks of home and family life, social relationships, civic duty, and service to mankind" (Aims of a BYU Education, n.d.). Since many of the projects focused on serving others and solving problems, the CID courses led to development of an attitude of lifelong learning and service to others. Students often met outside of scheduled time to continue work on their projects. Many continued to work on other aspects of the project even as the courses were completed.

\section{Library Faculty Participation}

As mentioned earlier, the library had the spirit of Switzerland where students and faculty were housed in a neutral place where everyone felt like they belonged but to which none had ownership. This atmosphere helped students feel and work as equals on projects. The dedicated space allowed students to stop and restart activities without the interruptions of putting away and bringing out materials. It facilitated team interactions as team members reconfigured furniture to develop a more unified work group or moved to attached group study rooms to break out into smaller working units.

Also critical was access to library faculty. As students discovered a need to delve deeper into their own discipline or a specific topic, librarians, embedded in the course, acted as guides to help students find the needed knowledge and understanding from library resources. Librarians taught students how to access, analyze, and evaluate sources of information pertinent to their learning. These interactions also fold into the university aims as they teach lifelong skills that facilitate cooperation and enable students to enlarge their intellectual abilities as needed.

\section{CID Challenges}

While the experiences of students and faculty were dominantly positive, several issues need to be resolved. First, the space for the prototypes was in a back corner on a "quiet" floor. While 
away from much of the study areas, noise does travel. The noise levels become problematic as students speak with one another during collaborations and want to celebrate breakthroughs in the project. In this space, conversations and celebrations had to be quieter and less exuberant than students wanted. The CID studio needs a space where noise is allowed or where there are barriers to prevent noise from traveling to quieter library areas.

Second, librarian participation was critical to and required of each course. To ensure this component and to book the space for learning activities, there needs to be a library coordinator for the CID space. They would ensure that the course connects to and uses the right librarians and resources for the CID project. This process ensures that the librarian is embedded in the CID course and makes them an integral part of student learning.

Third, not all students had the same depth of learning and cross discipline cooperation. The open learning concept was a difficult adjustment for some students. At times students needed some direction on where and how they could better fit into the team collaborations instead of just assuming their typical roles. Also, more instruction on how to overcome team differences and conflict is needed. This instruction, along with students' better understanding the concept of how the courses function, were critical to student learning.

Fourth, the limited space and available tools limited what courses could be taught in the space. Some faculty had classes they would like to have taught in the space but could not because of CID studio's size limitations and lack of specialized materials. The CID space needs to be of sufficient size to meet course enrollment needs. In addition, co-location of the space next to critical library resources is essential. Locating the CID space next to a makerspace or media lab is preferred over locating it near library services that do not meet CID needs. 
Finally, teaching these courses required a teaching and grading adjustment for faculty. Those teaching these courses truly became "guides on the side" instead of "sages on the stage." Instruction focused on helping students get over obstacles to success in the course or helping them to understand how to work with one another, especially when personality conflicts took place. Additionally, grading is somewhat problematic as traditional tests and assignments are not given. Students must produce learning and artifacts that provide an indication of their

contribution to the team's work and their personal learning. Both the instruction and marking can be a challenge for faculty who are new to this type of learning space and the education it fosters.

\section{Implementing a CID Studio}

While this case study focuses on the experience of one library, lessons may be applied to those wishing to create such a space in their academic library. Efforts should start with identifying faculty who teach creativity and innovation classes on campus within their discipline. This survey of courses includes the type of course taught, where it is taught, its interdisciplinary nature, equipment and resources needed for teaching the course, if the course is interdisciplinary in nature, and, most importantly, what the faculty would like to have to improve their course. Assessing these factors will determine if the library is a good fit for meeting some of the needs of those teaching the courses.

Additionaly a review of librarians and the space for which they are responsible is needed. If a space is to be developed in the library, librarians must devote space, in an appropriate location within the library, for classes to be taught. This review would also match the course objectives with library goals and university aims to determine if there is a positive match and reason for having a CID studio. Another condition would be that the courses fully engage librarians as part 
of the course instruction. This results in the library becoming partners with faculty instead of just being landlords.

Once these two hurdles are overcome, if faculty would like to teach in the library and the library is willing to devote resources, personnel and space, many of the other procedures outlined earlier would be helpful check points. Courses should be promoted across campus as being interdisciplinary and a benefit to students' program of studies. Each CID studio and its use policies should be catered to meet the educational goals for students outlined by the university. As was the case in this study, each experience will be unique and unfold in expected and unexpected ways. Patience, flexibility, and communication are critical to success.

\section{Conclusion}

The CID studio presents a new opportunity for integrating library resources and skills into classrooms that foster new learning and deeper understanding. It requires a shift in thinking from libraries as quiet repositories of knowledge to interactive places of knowledge creation and lifelong skill development.

Taking small steps and using a prototype within each library provides insights into how this type of space facilitates student learning and cooperation. It also opens new venues of collaboration and understanding between librarians and their subject-specific counterparts. It changes the nature of education and learning from a course with specific objectives to an experience that fosters lifelong learning, deeper understandings, and stronger collaborations.

\section{Recommendations for Future Development}

As our CID studio is a prototype, our assessment of the CID space in the Lee Library lists four recommendations for future development. These include: 
1. Expand the CID studio so it can house larger classes and a greater variety of innovative projects. This expansion should include a space that allows for greater noise or barriers (i.e., glass walls) that prevent noise from spreading to other library areas.

2. Bring specialized equipment that facilitates the integration of interdisciplinary projects into the space. This equipment includes production and technology typically found elsewhere on campus or basic equipment such as printers (including 3-D), and projectors.

3. Both library and nonlibrary faculty need further training on how to collaborate better. This includes librarians understanding the project and instructors understanding the library resources and librarian expertise.

4. The CID studio needs continuous promotion across campus as a neutral, specialized teaching space that facilitates deeper learning. 


\section{References}

“Aims of a BYU Education”, (2014), available at: http://aims.byu.edu/aims (accessed 1 April 2017).

Banahan, E., \& Playfoot, J. (2004), "Socio-organizational challenges in the creative economy", In Camarinha-Matos, L. M. \& Afsarmanesh, H. (Eds.), Collaborative networked organizations: A research agenda for emerging business models. Kluwer Academic: Boston.

Berland, E. (2012), "Creativity and education: Why it matters", available at: http://wwwimages.adobe.com/www.adobe.com/content/dam/Adobe/en/education/pdfs/ad obe-creativity-education-findings.pdf?trackingid=KFBUZ (accessed 1 April 2017).

Bieraugel, M. \& Neill, S. (2017). “Ascending Bloom’s pyramid: Fostering student creativity and innovation in academic library spaces", College \& Research Libraries, Vol. 78, No. 1, pp. 35-52.

Brandt, C. B., Cennamo, K., Douglas, S., Vernon, M., McGrath, M., \& Reimer, Y. (2011). “A theoretical framework for the studio as a learning environment", International Journal of Technology and Design Education, Vol. 23, No. 2, pp. 329-348.

https://doi.org/10.1007/s10798-011-9181-5

Broadfoot, O., \& Bennett, R. (2003). "Design studios: Online? Comparing traditional face-toface design studio education with modern internet-based design studios", In Apple University Consortium Academic and Developers Conference Proceedings 2003, pp. 921). Adelaide, Australia. Retrieved from http://citeseerx.ist.psu.edu/viewdoc/download;jsessionid=E36FCCD1F9EB81E5B9D66D 1014D59989?doi=10.1.1.124.3548\&rep=rep1\&type=pdf 
Brocato, K. (2009). "Studio based learning: Proposing, critiquing, iterating our way to personcenteredness for better classroom management", Theory into Practice, Vol. 48, No. 2, 138-146. https://doi.org/10.1080/00405840902776459

“BYU mission statement”, (2014), available at: http://aims.byu.edu/mission_statement (accessed 1 April 2017).

Cennamo, K., \& Brandt, C. (2012). "The "right kind of telling": Knowledge building in the academic design studio", Educational Technology Research and Development, Vol. 60, No. 5, pp. 839-858. https://doi.org/10.1007/s11423-012-9254-5

Coakes, E., \& Smith. P. (2007). “Developing communities of innovation by identifying innovation champions", Learning Organization, Vol. 14, No. 1, pp. 74-85.

Curry, R., (2017). “Makerspaces: A beneficial new service for academic libraries?” Library Review, Vol. 66, No. 4/5, pp. 201-212.

Gupta, A. (2015). "The university of the 21st century: A catalyst for creativity and innovation". Retrieved from https://open.library.ubc.ca/cIRcle/collections/ubcpresidentsspeechesandwritings/ $\underline{53169 / \text { items } / 1.0108012}$

Ogunleye, J. (2006). “A review and analysis of assessment objectives of academic and vocational qualifications in English further education, with particular reference to creativity", Journal of Education \& Work, Vol. 19, No. 1, pp. 95-104.

Paustenbaugh, J. (2013). “Strategic Thinking”, Unpublished Manuscript available at: https://intranet.lib.byu.edu/images/1/1b/Strategic thinking 3Dec13.pptx (accessed 1 April 2017). 
"Partnership for 21st century skills: Framework for 21st century learning”, (2014), available at: http://www.p21.org/about-us/p21-framework (accessed 1 April 2017).

Soulé, H., \& Warrick, T. (2015). “Defining 21st century readiness for all students: What we know and how to get there?" Psychology of Aesthetics, Creativity, and the Arts, Vol. 9, No. 2, pp. 178 . Retrieved from http://psycnet.apa.org/journals/aca/9/2/178/ 


\section{Appendix A: Description of Courses Taught in CID Studio}

Where possible, the following descriptions include the course name, instructor(s) and their college affiliation, and a description of the course taught.

Fundación Paraguay. Jeff Sheets (Laycock Center Director) and Todd Manwaring (Ballard Center for Economic Self-Reliance) challenged students to design a product that would generate social change. Students collaborated with Martin Burt, founder of Fundación Paraguaya, to promote Burt's Poverty Stoplight program. This program creates statistical and visual representations of poverty in Paraguay ("Fundacion Paraguaya: Poverty stoplight," 2014). The data identified how to best help families and can be shared with other nonprofit organizations. Students worked together to create a commercial and documentary for the organization. A small group of students also traveled to Paraguay to meet with Burt, conduct interviews, and collect film footage.

Children's storybooks creation. Students from the English, Visual Arts, and Advertising disciplines worked together to write, illustrate, and publish children's books.

Alternate reality science game (DUST) design and promotion. Jeff Sheets (Laycock Center Director), Derek Hansen (College of Engineering and Technology), and Steven Shumway (College of Engineering and Technology) led students in this Spring 2014 course. Students collaborated with the University of Maryland, NASA, and the Computer History Museum to develop and promote an alternate reality game focused on teaching science principles to teenagers. The National Science Foundation funded this project and students plan to continue with the project through 2016.

Innovation boot camp. This two-day course focused on giving students exposure to design thinking as an innovation process. The instructor (Dr. Taylor Halverson, Center for Teaching and Learning) split the students into three groups. On the first day, he taught students an immersive process for design thinking. During the following week, each team designed an individual study carrel for the library. On the final day of class, the teams presented their designs to four university librarians.

Artifacts development for the DUST project. Guided by Rick West, students developed artifacts for use in the DUST alternate reality game.

Scripture study tools innovation. Led by Jeff Sheets and Taylor Halverson, students innovated methods to facilitate frequent and effective scripture study. For example, one group of students developed a Facebook group that posted scripture-based memes.

Farm Country at Thanksgiving Point design. Andrew Gibbons (Instructional Psychology and Technology) helped students create new exhibits for Thanksgiving Point's Farm Country. Student ideas included an interactive, playground-like tree, and an international farm simulation.

CEO for a biotech company. Marc Hansen helped the students in the course act as a CEO for a biotech company. Students worked with company shareholders to refine the company's vision and mission statement. Students helped develop a new company mission statement and slogan, as well as directed use of company assets.

Individual social innovation projects. Aaron Miller (Marriott School) mentored students as they developed their own social innovation projects such as an internship program for at-risk high school students and a service organization run by professional athletes.

Resources for Fundación Paraguaya. The students produced a website and other materials for the Fundación Paraguaya project. 
Diplomacy museum for National Mall. The students developed a diplomacy museum for the National Mall. Students interviewed individuals from several countries that embody principles of diplomacy. Jeff Sheets and Cory Leonard (Kennedy Center) led this course.

Alternate reality game for BYU writing course. Derek Hansen and Jon Balzotti (English) led this course focused on developing an alternate reality game for a BYU technical writing course.

Experience design. Taught by Patty Freeman and Mat Duerden (Marriott School), this course focused on experience design in the recreation management field. Projects included managing a recreation department for Sanpete County, enhancing the customer experience at Provo Beach Resort, and improving facilities at Ticaboo Resort.

Solutions journalism. Alicia Gettys (Ballard Center) taught students techniques of solutions journalism.

Individual social innovation projects. Aaron Miller helped students develop their social innovation ideas. 


\section{Appendix B: All Questions on Surveys and in Interviews and Focus Groups}

We administered the full survey four times: April 2014, June 2014, December 2014, and April 2015. Scaled questions were identical in all surveys, but open-response questions differed slightly. Additionally, we administered a pre-course survey in September 2014 and January 2015. Questions also include those specifically for students only and specifically for faculty only.

\section{April 2014}

\section{Nonscaled Questions}

1. What is your major?

2. What year are you in school?

3. What is your gender?

4. How useful was the experience overall for you as a student? Please explain and give specific examples.

5. How does this type of experience compare with your other BYU learning experiences?

6. What kinds of things did you learn?

7. What are the strengths and weaknesses of this approach?

8. How can we improve the usefulness of the space where the class was taught and of the experience itself?

9. With whom did you engage (students, faculty library personnel) to complete the project?

10. What places on/off campus did you use to work on the project?

11. What kind of services were helpful in completing the project?

12. What kind of tools and supplies were helpful in completing the project?

\section{June 2014}

1. Which college and department are you from?

2. What year are you in school?

3. What is your gender?

4. How useful was the experience in this class and/or participating in this project overall for you as a student? Please explain and give specific examples.

5. How does this type of experience compare with your other BYU learning experiences?

6. What are the strengths and weaknesses of this approach?

7. How did the space and location for the class (in the library) contribute to or detract from the learning experience? Please give specific examples.

8. How can we improve the usefulness of the space where the class was taught and of the experience itself?

9. What did you learn, if anything, this semester related to your content area? Please give specific examples.

10. What, if anything, did you learn this semester not related to your content area? For example, consider other content areas, or even noncontent learning such as how to be more creative, collaborative, etc. Please give specific examples.

11. Outside of your instructors, did you work with or learn from anyone else to help you in this class? For example, consider librarians, other faculty or students from your department, outside professionals, etc. If so, please list who they were and what they helped you with.

12. What places and resources on/off campus did you use to work on the project? 


\section{April 2015}

1. Which college and department are you from?

2. Which course are you enrolled in?

3. What year are you in school?

4. What is your gender?

5. How useful was the experience in this class and/or participating in this project overall for you as a student? Please explain and give specific examples.

6. How does this type of experience compare with your other BYU learning experiences? What are the strengths and weaknesses of this approach?

7. How did the space and location for the class (in the library) contribute to or detract from the learning experience? Please give specific examples.

8. How can we improve the usefulness of the space where the class was taught and of the experience itself?

9. What did you learn, if anything, this semester related to your content area? Please give specific examples.

10. What, if anything, did you learn this semester not related to your content area? For example, consider other content areas, or even noncontent learning such as how to be more creative, collaborative, etc. Please give specific examples.

11. Outside of your instructors, did you work with or learn from anyone else to help you in this class? For example, consider librarians, other faculty or students from your department, outside professionals, etc. If so, please list who they were and what they helped you with.

12. What places and resources on/off campus did you use to work on the project?

\section{September 2014 (Pre-course survey)}

1. Which college are you from?

2. What year are you in school?

3. What is your gender?

4. What are your reasons for registering for this course? Please be specific.

5. What do you hope to learn this semester in your content area (discipline)?

6. Is there anything you hope to learn this semester not related to your content area? Please give specific examples.

\section{December 2014}

1. Which college and department are you from?

2. What year are you in school?

3. What is your gender?

4. What course are you enrolled in?

5. What other innovation or creativity courses have you taken? Please be specific-provide course number and semester if possible.

6. How useful was the experience in this class and/or participating in this project overall for you as a student? Please explain and give specific examples.

7. How does this type of experience compare with your other BYU learning experiences? What are the strengths and weaknesses of this approach? 
8. How did the space and location for the class (in the library) contribute to or detract from the learning experience? Please give specific examples.

9. How can we improve the usefulness of the space where the class was taught and of the experience itself?

10. What did you learn, if anything, this semester related to your content area? Please give specific examples.

11. What did you learn, if anything, this semester not related to your content area? For example, consider other content areas, or even noncontent learning such as how to be more creative, collaborative, etc. Please give specific examples.

12. Outside of your instructors, did you work with or learn from anyone else to help you in this class? For example, consider librarians, other faculty or students from your department, outside professionals, etc. If so, please list who they were and what they helped you with.

13. What places and resources on/off campus did you use to work on the project?

\section{Student Only Questions}

\section{Focus group interview questions}

1. How was this class similar or different from other classes you've had at BYU?

2. In this project, you worked on a very diverse team with people who have different perspectives or disciplines. What benefit or challenges did this collaboration provide?

3. What are your thoughts about having the class and project here in the library space? What worked well about the arrangement? What could be improved?

4. Who did you work with (librarians, other faculty) to complete your project? Please describe how you discovered them. How helpful was it?

5. What did you learn from the project that related specifically to your content area?

6. What did you learn from the project that was outside of your content area?

7. Did you learn anything that is not at all related to school that you thought was important? What was it, and how did you learn it? (Creative process? Project management? Teamwork?)

8. Would you take a class like this again, similar structure but different project? Why or why not?

9. Tell me the three most important things or events that were critical to this project?

10. How did those events occur? Who was involved? What happened? How did you develop the ideas?

\section{Questions for informal interviews during observations}

1. What is currently happening in the design (creativity process)?

2. How do you feel about what is happening? (What is working well; what is not?)

3. What surprises you about the creativity process thus far?

4. What resources are available to help you with your project?

5. What do you anticipate will happen next?

\section{Additional questions for innovation boot camp participants}

1. Describe your role on your team.

2. Did you feel listened to and validated by your team? Explain. 
3. How well do you feel the team worked together?

\section{Faculty Only Questions}

\section{Faculty who taught in CID studio}

1. Tell me about your class project and the students involved.

2. How was teaching this course the same as/different from teaching other courses?

3. In what ways were student interactions different in this course than other courses?

4. How has teaching in the CID studio affected how you teach courses not held in the CID studio?

5. How did you collaborate with other faculty members (library and nonlibrary)? What challenges and benefits did teaching in the CID studio create?

6. Did you interact with any librarians or use any library resources for your course, and if so, how?

7. In what way could we improve the library space?

8. Why did you choose to teach your course in the CID studio?

9. What surprises have happened in your class?

10. How do you feel about holding your class in the library?

\section{Faculty that chose not to teach in CID studio}

1. Have you taught a class in the CID studio before?

2. What creativity, innovation, or design classes do you teach?

3. Why did you choose not to teach in the CID studio?

4. Imagine there were no limits. What support, infrastructure, and situations would have made it so you would have taught in the CID studio? 


\section{Appendix C: Results of Scaled Survey Questions: Course Experience}

The following questions were administered on each survey and students were asked to rate the statement as it related to their learning experience with 1 meaning "strongly disagree" and 5 meaning "strongly agree."

\begin{tabular}{lcc}
\hline \multicolumn{1}{c}{ Statement } & $n$ & $\mathrm{M}(\mathrm{SD})$ \\
\hline $\begin{array}{l}\text { I had a deep, personal motivation to do well on this project beyond just for my } \\
\text { grade. }\end{array}$ & 103 & $4.15(1.00)$ \\
I felt responsibility for my portion of this project and for making it as good as & 103 & $4.45(0.81)$ \\
possible. & 103 & $4.17(0.97)$ \\
I had freedom to make choices about the design of my portion of the project. & 103 & $4.18(0.96)$ \\
I was able to choose the kind of role I played on the team and the kind of work I & 103 & $3.88(0.99)$ \\
completed on the project. & 103 & $3.37(1.27)$ \\
Prototyping helped us make the project more creative and of a higher quality. & 103 & $3.73(1.06)$ \\
I felt like everyone in the group was on equal footing and authority. & 103 & $3.94(0.93)$ \\
In this experience, I learned in part by critiquing the work of others. & 103 & $4.17(0.92)$ \\
In this experience, I learned through the critiques others gave me. & 103 & $4.2(0.94)$ \\
I felt like the instructor was a mentor and a consultant more than a typical & & \\
teacher. & &
\end{tabular}

